\title{
Assessment of Undiscovered Oil and Gas Resources in the Spraberry Formation of the Midland Basin, Permian Basin Province, Texas, 2017
}

\author{
Using a geology-based assessment methodology, the U.S. Geological Survey estimated mean resources of 4.2 billion barrels of oil \\ and 3.1 trillion cubic feet of gas in the Spraberry Formation of the Midland Basin, Permian Basin Province, Texas.
}

\section{Introduction}

The U.S. Geological Survey (USGS) completed a geologybased assessment of undiscovered, technically recoverable continuous and conventional oil and gas resources in the Spraberry Formation within the Midland Basin of the Permian Basin Province in west Texas. Historically, the Spraberry Formation has been exploited primarily through vertical drilling, and continual increase in drilling depths and perforations within both the Spraberry Formation and the underlying Wolfcamp shale has resulted in the development of the informal Wolfberry play across the Spraberry (trend area) field (Hamlin and Baumgardner, 2012; Railroad Commission of Texas, 2014). The Spraberry was last assessed in 2007 based on historical production from vertical wells (Schenk and others, 2007). Since 2007, multiple intervals within the Spraberry have been targeted with horizontal drilling.

\section{Geologic Summary}

The Lower Permian (Leonardian) Spraberry Formation primarily consists of interbedded sandstone, siltstone, carbonate, and organic-rich shale, which were deposited in a deepwater marine environment in the Midland Basin. The Midland Basin is the eastern subbasin of the greater Permian Basin and is rimmed by carbonate platforms such as the Central Basin platform, Eastern shelf, and Northern shelf (fig. 1). The Spraberry Formation is informally divided into the upper, middle, and lower Spraberry intervals (Hamlin and Baumgardner, 2012). In the southern part of the basin, production from continuous reservoirs is extensive across the greater Spraberry (trend area) field. In the northern section of the basin, conventional Spraberry production occurs where multiple intervals of the Spraberry Formation and the underlying Dean Formation are productive from discrete fields.

\section{Total Petroleum System and Assessment Units}

Two continuous and one conventional assessment units (AUs) were defined and quantitatively assessed for the Spraberry Formation in the Midland Basin: (1) Middle Spraberry Continuous Oil Trend AU, (2) Lower Spraberry Continuous Oil Trend AU, and (3) Northern Spraberry Conventional Oil AU (fig. 1). All three assessment units are within the Permian Basin Paleozoic Composite Total Petroleum System (Schenk and others, 2007; Gaswirth and others, 2016). The two continuous AUs are identical in extent and are bounded to the west by the Central Basin platform, to the east by the Eastern shelf basin margin, to the north by the approximate southern edge of the Horseshoe atoll and to the south by the Val Verde Basin (Schenk

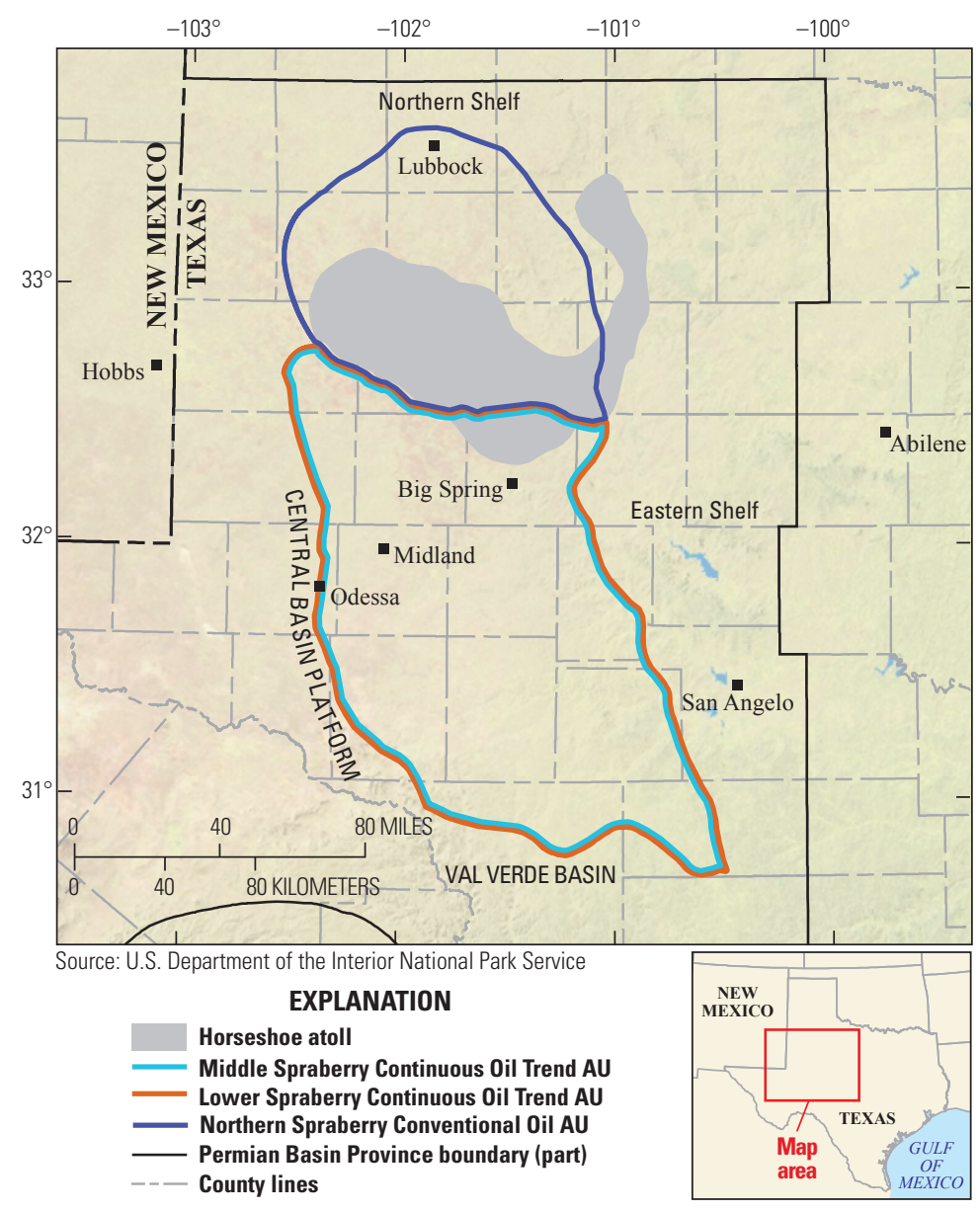

Figure 1. Map showing key geologic features and the boundaries of the continuous and conventional assessment units (AUs) defined for the Spraberry Formation in the Midland Basin, Permian Basin Province, Texas. The two continuous AUs are identical in extent.

and others, 2016). The Middle Spraberry Continuous Oil Trend AU covers the interval of the informal middle Spraberry. The Lower Spraberry Continuous Oil Trend AU consists of strata of the informal lower Spraberry interval and includes the industry-termed (informal) lower Spraberry shale and Jo Mill siltstone. The Northern Spraberry Conventional Oil AU encompasses the entire Spraberry Formation across the Horseshoe atoll and into the northern part of the basin where conventional Spraberry fields exist. The conventional AU is bounded by the shelf margins of the Midland Basin to the north and east and includes the extent of Spraberry drilling to the west. Key input data used to assess the Spraberry Formation are listed in table 1. 


\section{Undiscovered Resources Summary}

The USGS assessed undiscovered, technically recoverable continuous and conventional mean oil and gas resources for three AUs defined in the Spraberry Formation (table 2). Total estimated mean resources are 4,245 million barrels of oil (MMBO), or 4.2 billion barrels of oil, with an F95-F5 range from 1,873 to 7,635 MMBO; 3,112 billion cubic feet of gas (BCFG), or 3.1 trillion cubic feet of gas, with an F95-F5 range from 1,080 to 6,200 BCFG; and 311 million barrels of natural gas liquids (MMBNGL) with an F95-F5 range from 100 to 652 MMBNGL. The majority of these resource estimates are within the two continuous AUs. Mean resources of 5 MMBO with an F95-F5 range from 3 to 10 MMBO and 3 BCFG with an F95-F5 range from 1 to 5 BCFG are attributed to the Northern Conventional Spraberry Oil AU.

Table 1. Key assessment input data for the three assessment units in the Spraberry Formation, Texas.

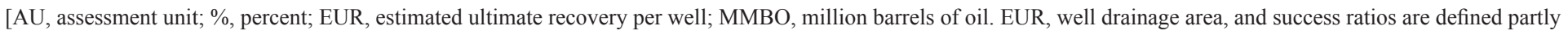
using U.S. shale-oil analogs. The average EUR input is the minimum, median, maximum, and calculated mean. Shading indicates not applicable]

\begin{tabular}{|c|c|c|c|c|c|c|c|c|}
\hline \multirow{2}{*}{ Assessment input data } & \multicolumn{4}{|c|}{ Middle Spraberry Continuous Oil Trend AU } & \multicolumn{4}{|c|}{ Lower Spraberry Continuous Oil Trend AU } \\
\hline & Minimum & Mode & Maximum & Calculated mean & Minimum & Mode & Maximum & Calculated mean \\
\hline Potential production area of AU (acres) & $2,315,000$ & $4,200,000$ & $6,215,000$ & $4,243,333$ & $2,315,000$ & $4,200,000$ & $6,215,000$ & $4,243,333$ \\
\hline Average drainage area of wells (acres) & 80 & 160 & 240 & 160 & 60 & 80 & 240 & 127 \\
\hline Success ratios $(\%)$ & 80 & 90 & 95 & 88.3 & 80 & 90 & 95 & 88.3 \\
\hline Average EUR (MMBO) & 0.08 & 0.12 & 0.3 & 0.130 & 0.1 & 0.17 & 0.3 & 0.176 \\
\hline AU probability & 1.0 & & & & 1.0 & & & \\
\hline \multirow{2}{*}{ Assessment input data } & \multicolumn{4}{|c|}{ Northern Spraberry Conventional Oil AU } & & & & \\
\hline & Minimum & Median & Maximum & Calculated mean & & & & \\
\hline Number of undiscovered fields & 1 & 4 & 10 & 4.19 & & & & \\
\hline Sizes of undiscovered fields (MMBO) & 0.5 & 1 & 10 & 1.27 & & & & \\
\hline AU probability & 1.0 & & & & & & & \\
\hline
\end{tabular}

Table 2. Assessment results for three assessment units in the Spraberry Formation, Texas.

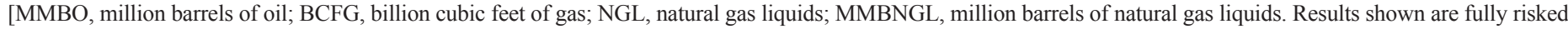
estimates. For gas accumulations, all liquids are included in the NGL category. F95 represents a 95-percent chance of at least the amount tabulated; other fractiles are defined similarly. Fractiles are additive under the assumption of perfect positive correlation. Shading indicates not applicable]

\begin{tabular}{|c|c|c|c|c|c|c|c|c|c|c|c|c|c|c|}
\hline \multirow{3}{*}{$\begin{array}{l}\text { Total petroleum system } \\
\text { and assessment units (AUs) }\end{array}$} & \multirow{3}{*}{$\begin{array}{c}\text { AU } \\
\text { prob- } \\
\text { ability }\end{array}$} & \multirow{3}{*}{$\begin{array}{c}\text { Accu- } \\
\text { mulation } \\
\text { type }\end{array}$} & \multicolumn{12}{|c|}{ Total undiscovered resources } \\
\hline & & & \multicolumn{4}{|c|}{ Oil (MMBO) } & \multicolumn{4}{|c|}{ Gas (BCFG) } & \multicolumn{4}{|c|}{ NGL (MMBNGL) } \\
\hline & & & F95 & F50 & F5 & Mean & F95 & F50 & F5 & Mean & F95 & F50 & F5 & Mean \\
\hline \multicolumn{15}{|c|}{ Permian Basin Paleozoic Composite Total Petroleum System } \\
\hline Middle Spraberry Continuous Oil Trend AU & 1.0 & Oil & 632 & 1,352 & 2,593 & 1,447 & 366 & 959 & 2,100 & 1,061 & 34 & 93 & 222 & 106 \\
\hline Lower Spraberry Continuous Oil Trend AU & 1.0 & Oil & 1,238 & 2,593 & 5,032 & 2,793 & 713 & 1,841 & 4,095 & 2,048 & 66 & 180 & 429 & 205 \\
\hline Total undiscovered continuous resources & & & 1,870 & 3,945 & 7,625 & 4,240 & 1,079 & 2,800 & 6,195 & 3,109 & 100 & 273 & 651 & 311 \\
\hline Northern Spraberry Conventional Oil AU & 1.0 & Oil & 3 & 5 & 10 & 5 & 1 & 2 & 5 & 3 & 0 & 0 & 1 & 0 \\
\hline Total undiscovered conventional resources & & & 3 & 5 & 10 & 5 & 1 & 2 & 5 & 3 & $\mathbf{0}$ & $\mathbf{0}$ & 1 & $\mathbf{0}$ \\
\hline Total undiscovered resources & & & 1,873 & 3,950 & 7,635 & 4,245 & 1,080 & 2,802 & 6,200 & 3,112 & 100 & 273 & 652 & 311 \\
\hline
\end{tabular}

\section{References Cited}

Gaswirth, S.B., Marra, K.R., Lillis, P.G., Mercier, T.J., Leathers-Miller, H.M., Schenk, C.J., Klett, T.R., Le, P.A., Tennyson, M.E., Hawkins, S.J., Brownfield, M.E., Pitman, J.K., and Finn, T.M., 2016, Assessment of undiscovered continuous oil resources in the Wolfcamp shale of the Midland Basin, Permian Basin Province, Texas, 2016: U.S. Geological Survey Fact Sheet 2016-3092, 4 p.

Hamlin, H.S., and Baumgardner, R.W., 2012, Wolfberry (WolfcampianLeonardian) deep-water depositional systems in the Midland BasinStratigraphy, lithofacies, reservoirs, and source rocks: University of Texas at Austin, Bureau of Economic Geology, Report of Investigations No. 277, 61 p.

Railroad Commission of Texas, 2014, Final order amending field rules for the Spraberry (trend area) field, various counties, Texas: Railroad Commission of Texas, Hearings Division, Consolidated Oil and Gas Docket Nos. 7C-0291169 and 7C-0291171, 9 p., accessed March 1, 2017, at http://www.rrc.state.tx.us/ media/25459/7c-91169-1171afr-ord.pdf.

Schenk, C.J., Pollastro, R.M., Cook, T.A., Pawlewicz, M.J., Klett, T.R., Charpentier, R.R., and Cook, H.E., 2007, Assessment of undiscovered oil and gas resources of the Permian Basin Province of west Texas and southeast New Mexico: U.S. Geological Survey Fact Sheet 2007-3115, 4 p.

Schenk, C.J., Tennyson, M.E., Klett, T.R., Mercier, T.J., Brownfield, M.E., Gaswirth, S.B., Hawkins, S.J., Leathers-Miller, H.M., Marra, K.R., Finn, T.M., and Pitman, J.K., 2016, Assessment of tight-gas resources in Canyon sandstones of the Val Verde Basin, Texas, 2016: U.S. Geological Survey Fact Sheet 2016-3039, 2 p.

\section{Spraberry Formation Assessment Team}

Kristen R. Marra, Stephanie B. Gaswirth, Christopher J. Schenk, Heidi M. Leathers-Miller, Timothy R. Klett, Tracey J. Mercier, Phuong A. Le, Marilyn E. Tennyson, Thomas M. Finn, Sarah J. Hawkins, and Michael E. Brownfield

\section{For More Information}

Assessment and methodology information can be accessed at the USGS Energy Resources Program website at https://energy.usgs.gov. 